\title{
Three Different Types of Activated Carbon and Manganese-Modified Activated Carbons as Deoxidizers for the Low-Concentration Coalbed Methane Deoxidation
}

\author{
Guojie Zhang, ${ }^{\odot *, a, b}$ Peng Hou, ${ }^{a}$ Yinghui Sun, ${ }^{a}$ Ying Xu, ${ }^{a}$ Haizhu Cheng ${ }^{a}$ and \\ Yongfa Zhang ${ }^{a}$ \\ ${ }^{a}$ Key Laboratory of Coal Science and Technology, Ministry of Education and Shanxi Province, \\ Taiyuan University of Technology, 030024 Taiyuan, Shanxi, P. R. China \\ ${ }^{b}$ College of Chemical Engineering, Qingdao University of Science and Technology, \\ 53 Zhengzhou Road, 266042 Qingdao, P. R. China
}

\begin{abstract}
Different activated carbons and manganese-modified activated carbons were prepared as deoxidizers for the low-concentration coalbed methane deoxidation. The results show that the deoxidation performance of the different activated carbons is affected by raw materials for preparation of deoxidizers. One type of activated carbon exhibited the best performance of oxygen removal, due to the relatively low ash content and better adsorption performance. Experimental results show that the manganese-modified deoxidizers exhibit an excellent deoxidation efficiency at low temperature. At $200{ }^{\circ} \mathrm{C}$, one kind of manganese-modified activated carbons decreased the oxygen content to less than $1 \mathrm{vol} \%$, which could maintain about $600 \mathrm{~min}$. This indicated that the addition of manganese greatly improved the reactivity of oxygen with activated carbon. Characterization results demonstrated that the physical structure and species types of oxygen of activated carbons, and manganese have important effects on the activity of deoxidizers in different temperature ranges.
\end{abstract}

Keywords: coalbed methane, activated carbon, deoxidizer, potassium permanganate

\section{Introduction}

Coalbed methane is a by-product of coal mining. It is a new type of clean energy. Coalbed methane extraction is mainly divided into two methods: ground and underground extraction. The coalbed methane extracted through the ground has high methane content and high utilization value. For coalbed methane extracted underground, the methane content is low and mixed with a large amount of air, resulting in an increased risk of explosion. This limits its utilization and pressure pipeline transportation, which is also the main factor that has been disrupting the largescale utilization of coalbed methane. At present, coalbed methane with $\mathrm{CH}_{4}$ concentration lower than $30 \%$ is mainly treated by incineration destruction or dispersal, resulting in an annual discharge of up to 19 billion cubic meters, equivalent to more than 200 million tons of standard coal. This not only caused a lot of waste of resources, but also caused great damage to the ecological environment. ${ }^{1,2}$ The development and utilization of low-concentration coalbed

*e-mail: zhangguojie@tyut.edu.cn, zhgjdoc@126.com methane can not only improve the utilization rate of coalbed methane, make up for energy shortage, reduce greenhouse effect, develop low-carbon economy, reduce environmental pollution, but also reduce or avoid gas explosion accidents, which have a safety effect. ${ }^{1}$ Therefore, the development and utilization of coalbed methane has attracted great attention from the state and society.

If the low concentration oxygen-containing coalbed methane is directly enriched and concentrated, the $\mathrm{O}_{2}$ concentration would increase with the increase of $\mathrm{CH}_{4}$ concentration. In the end, the concentration of $\mathrm{O}_{2}$ reaches the explosive limit and increases the danger of operation. Therefore, deoxidation is a key constraint for the rational use of low-concentration oxygen-containing coalbed methane. There are lots of technical problems for coalbed methane deoxidation in home and abroad. At present, the main deoxidation technologies are as follows: low temperature cryogenic liquefaction separation, ${ }^{3-6}$ membrane separation, pressure swing adsorption separation, ${ }^{7-14}$ coke combustion deoxidation and catalytic combustion deoxidation. ${ }^{15,16}$ However, there are some operational inconvenience and hidden dangers for low temperature separation method, 
membrane separation and pressure swing adsorption method. The carbon combustion deoxidation is through direct combustion reaction of coke with $\mathrm{O}_{2}$ in coalbed methane to generate $\mathrm{CO}_{2}$ and $\mathrm{CO}$ to remove $\mathrm{O}_{2}$ from coalbed methane. Due to the higher reaction temperature, some $\mathrm{CH}_{4}$ will be cleaved to form $\mathrm{H}_{2}$. Thus, the most critical problem that we faced to solve is to reduce the reaction temperature and prevent the loss caused by $\mathrm{CH}_{4}$ cracking. ${ }^{17}$

Previous studies ${ }^{15,16}$ have found that using biomass charcoal as a deoxidizer, the deoxidation temperature can be reduced to less than $450{ }^{\circ} \mathrm{C}$, and it also has a high deoxidation efficiency. In order to further reduce the deoxidation temperature and improve deoxidation efficiency, in this paper, three different kinds of activated carbon and manganese modified activated carbon were used as deoxidizer for the low-concentration coalbed methane deoxidation. The deoxidation efficiency and performance for different deoxidizer were investigated.

\section{Experimental}

\section{Materials and sample preparation}

Three different types of activated carbon $\left(\mathrm{AC}_{\mathrm{x}}\right.$, $\mathrm{x}=1,2,3)$ were obtained from market. $\mathrm{AC}_{1}$ and $\mathrm{AC}_{2}$ were prepared from different types of coal $\left(\mathrm{AC}_{1}\right.$ from Jiaozuo Activated Carbon Company, Henan, China; $\mathrm{AC}_{2}$ form Xinhua Activated Carbon Company, Shanxi, China); $\mathrm{AC}_{3}$ was prepared from coconut husk (from Hunan Activated Carbon Company, Hunan, China). The three activated carbon particles have a particle size of about 40-60 mesh. Analytical pure potassium permanganate was obtained from Aladdin Industrial Corporation (Shanghai, China). The activated carbon was washed with deionized water 5 times before use, then it was dried at $105^{\circ} \mathrm{C}$ in a vacuum drying oven for $2 \mathrm{~h}$. The modified activated carbon was prepared by wet impregnation using the appropriate potassium permanganate solutions. The mixtures were stirred at $25^{\circ} \mathrm{C}$ for $4 \mathrm{~h}$, and then filtered and calcined at $500{ }^{\circ} \mathrm{C}$ for $2 \mathrm{~h}$, marked as $\mathrm{Mn} / \mathrm{AC}_{1}, \mathrm{Mn} / \mathrm{AC}_{2}$ and $\mathrm{Mn} / \mathrm{AC}_{3}$.

\section{Deoxidation of coalbed methane (CBM)}

Deoxidation of coalbed gas was carried out by a fixed-bed reactor. Prior to deoxidation reaction, $10 \mathrm{~g}$ of sample was dried under $\mathrm{N}_{2}$ flow $\left(100 \mathrm{~mL} \mathrm{~min}^{-1}\right)$ at $300^{\circ} \mathrm{C}$ for $2 \mathrm{~h}$. Then, the gas mixture containing $15 \% \mathrm{CH}_{4}-15 \%$ $\mathrm{O}_{2}-70 \% \mathrm{~N}_{2}$ with the total flow rate of $100 \mathrm{~mL} \mathrm{~min}^{-1}$ was introduced. The deoxidation performance was studied at different temperatures ranging from 200 to $350{ }^{\circ} \mathrm{C}$. The gas composition and content were measured by a gas chromatograph (GC-950, Shanghai Haixin) with thermal conductivity detector (TCD) using 5A molecular sieves column. After the completion of the deoxidation, the reactor was cooled to $25^{\circ} \mathrm{C}$ under a nitrogen atmosphere, and then a spent deoxidizer was taken out for characterization.

\section{Characterization}

The air was used as a carrier gas, and the weight change of the deoxidizer was evaluated by using a thermogravimetric (TG) analyzer (Netzsch STA 2500) at a heating rate of $10{ }^{\circ} \mathrm{C} \mathrm{min}-1$. The analysis of surface chemistry was conducted using an X-ray photoelectron spectrometer (XPS) utilizing monochromatic Al Ko source (ESCALAB 250Xi, Thermo Scientific). The X-ray diffraction (XRD) analysis of samples was measured on a Bruker D8 Advance diffractometer. ${ }^{8,9}$ Texture parameters of different deoxidizers were measured adopting a Builder Beishide 3H-2000PS2 automatic adsorption apparatus. ${ }^{9}$ The Fourier transform infrared (FTIR) analyses of samples were recorded on Nicolet Galaxy 5020 FTIR spectrometer. The morphologies of deoxidizers were measured by scanning electron microscopy (SEM, Hitachi S-4800). The dispersion details of deoxidizers were carried out by an energy dispersive X-ray spectrometer (EDS, Quantax400). $\mathrm{H}_{2}$-TPR (temperature-programmed reduction) was measured on Micromeritics AutoChem 2920 instrument.

\section{Results and Discussion}

\section{Physical characterization of samples}

Table 1 shows the surface area, average pore diameter and pore volume of the different activated carbon deoxidizers before and after reaction. BET (BrunauerEmmett-Teller) and pore volume of activated carbon deoxidizers are relatively large before activation $\left(\mathrm{AC}_{\mathrm{x}-\mathrm{b}}\right.$, $\mathrm{x}=1,2,3)$; after deoxidation $\left(\mathrm{AC}_{\mathrm{x}-\mathrm{a}}, \mathrm{x}=1,2,3\right)$, the values of all the activated carbon deoxidizers are greatly reduced. As shown in Table 1, the specific surface area for the $\mathrm{AC}_{1-\mathrm{b}}$ and $\mathrm{AC}_{3-\mathrm{b}}$ were similar before the reaction, 839.69 and $799.83 \mathrm{~m}^{2} \mathrm{~g}^{-1}$, respectively. The specific surface area for the $\mathrm{AC}_{2-\mathrm{b}}$ was larger: $930.72 \mathrm{~m}^{2} \mathrm{~g}^{-1}$. However, after deoxidation reaction, the value of $\mathrm{AC}_{3}$ decreased the most, from 799.83 to $266.07 \mathrm{~m}^{2} \mathrm{~g}^{-1}$. The specific surface area has decreased by varying degrees after reaction; this could be attributed to how the materials were prepared, where $\mathrm{AC}_{1}$ and $\mathrm{AC}_{2}$ were prepared from different types of coal, and $\mathrm{AC}_{3}$ was prepared from coconut husk. Due to the higher carbon content and lower ash content, $\mathrm{AC}_{3}$ is favorable for the oxidative deoxidation. After 
adding Mn modification, the specific surface area of all three different activated carbon deoxidizers are greatly decreased. The value of $\mathrm{Mn} / \mathrm{AC}_{2}$ decreased the most, from 492.78 to $39.99 \mathrm{~m}^{2} \mathrm{~g}^{-1}$. This indicates that the structure of $\mathrm{AC}_{2}$ undergoes some obvious change after modification by potassium permanganate, and more active metal particles are adsorbed on the surface and pores. ${ }^{18-20}$ This is conducive to the improvement of deoxidation activity. After deoxidation, the average pore diameter and pore volume of all activated carbon deoxidizers are greatly improved. Compared with the unmodified activated carbon $\mathrm{AC}_{\mathrm{x}}(\mathrm{x}=1,2,3)$, the specific surface area, pore volume and pore size of modified deoxidizers obviously change after reaction, which indicates that the activated carbon modified by high potassium acid is more susceptible to oxidation with oxygen, causing slight collapse of surface and pores, and micropores disappear partially. It also shows that the activity of the deoxidizer increased after loading the active metal manganese, which is consistent with the experimental results.

Table 1. Structural property of the different activated carbon (AC) deoxidizers

\begin{tabular}{lccc}
\hline Sample & $\begin{array}{c}\text { BET surface } \\
\text { area / }\left(\mathrm{m}^{2} \mathrm{~g}^{-1}\right)\end{array}$ & $\begin{array}{c}\text { Average pore } \\
\text { diameter } / \mathrm{nm}\end{array}$ & $\begin{array}{c}\text { Pore volume / } \\
\left(\mathrm{cm}^{3} \mathrm{~g}^{-1}\right)\end{array}$ \\
\hline $\mathrm{AC}_{1-\mathrm{b}}$ & 839.69 & 2.27 & 0.48 \\
$\mathrm{AC}_{1-\mathrm{a}}$ & 801.32 & 2.28 & 0.46 \\
$\mathrm{AC}_{2-\mathrm{b}}$ & 930.72 & 2.79 & 0.65 \\
$\mathrm{AC}_{2-\mathrm{a}}$ & 927.01 & 2.81 & 0.65 \\
$\mathrm{AC}_{3-\mathrm{b}}$ & 799.83 & 2.33 & 0.46 \\
$\mathrm{AC}_{3-\mathrm{a}}$ & 266.07 & 2.48 & 0.17 \\
$\mathrm{Mn} \mathrm{AC}_{1-\mathrm{b}}$ & 512.69 & 2.26 & 0.29 \\
$\mathrm{Mn}_{\mathrm{AC}}$ & 163.01 & 3.60 & 0.15 \\
$\mathrm{Mn} / \mathrm{AC}_{2-\mathrm{b}}$ & 492.78 & 2.75 & 0.34 \\
$\mathrm{Mn} / \mathrm{AC}_{2-\mathrm{a}}$ & 39.99 & 7.20 & 0.07 \\
$\mathrm{Mn} / \mathrm{AC}_{3-\mathrm{b}}$ & 464.96 & 2.35 & 0.27 \\
$\mathrm{Mn} / \mathrm{AC}_{3-\mathrm{a}}$ & 106.51 & 4.21 & 0.11 \\
\hline $\mathrm{Subscipted}$ & & &
\end{tabular}

Subscripted a and $\mathrm{b}$ represent the sample after and before the reaction, respectively. BET: Brunauer-Emmett-Teller.

Potassium permanganate modified activated carbon improved the deoxidation performance. Especially, $\mathrm{Mn} / \mathrm{AC}_{2}$ catalyst exhibited the best deoxidation performance at $200{ }^{\circ} \mathrm{C}$. To explore the effects of physical parameters on the deoxidation performance of activated carbon deoxidizers, some samples were chosen to study $\mathrm{N}_{2}$ physical adsorption/desorption performance. The results show that $\mathrm{N}_{2}$ adsorption-desorption isotherms of the different deoxidizers samples were consistent with the presence of micropores and mesopores as each produced
type-I and IV isotherms, suggesting that the $\mathrm{AC}_{\mathrm{x}}$ structure was not altered by impregnation of $\mathrm{Mn}$. The pore size distribution map before and after the reaction of different deoxidizer samples is also consistent with the BET analysis results.

In addition, by comparing the results of deoxidation test and characterization analysis, it can be seen that the surface area, pore size and pore volume of the deoxidizer are not the decisive factors for increasing the deoxidation activity. This is consistent with previous related researches ${ }^{21,22}$ that the performance of activated carbon is more dependent on surface chemistry than physical properties.

\section{$\mathrm{H}_{2}$-TPR analysis}

To investigate the effects of the potassium permanganate modification on the activated carbon deoxidizer reducibility, $\mathrm{H}_{2}$-TPR experiment was carried out. Figure 1 presents the $\mathrm{H}_{2}$-TPR profiles of $\mathrm{Mn} / \mathrm{AC}_{\mathrm{x}}(\mathrm{x}=1,2,3)$ deoxidizers with different activated carbon. The $\mathrm{H}_{2}$-TPR profiles of three different kinds of deoxidizers displayed two reduction peaks, which are assigned to the stepwise reduction of manganese species. The higher temperature peak is ascribed to the reduction of $\mathrm{Mn}_{2} \mathrm{O}_{3} / \mathrm{Mn}_{3} \mathrm{O}_{4}$. The low temperature peak is attributed to the reduction of $\mathrm{MnO}_{2} / \mathrm{Mn}_{2} \mathrm{O}_{3}$. Moreover, with activated carbon types from $\mathrm{AC}_{1}$ to $\mathrm{AC}_{3}$, there is a gradual shift of this low temperature reduction signal from 420 to $475{ }^{\circ} \mathrm{C}$, confirming the formation of larger-sized bulk $\mathrm{Mn}_{2} \mathrm{O}_{3} / \mathrm{Mn}_{3} \mathrm{O}_{4}$ particles. The broad reduction peak on $\mathrm{Mn} / \mathrm{AC}_{2}$ and $\mathrm{Mn} / \mathrm{AC}_{3}$ deoxidizers indicates variations in the extent of manganese activated carbon interactions. Reduction peak temperature indicates the reducibility of deoxidizers, and the lower temperature of the reduction peak means stronger reducibility. ${ }^{23-26}$ So the activity of

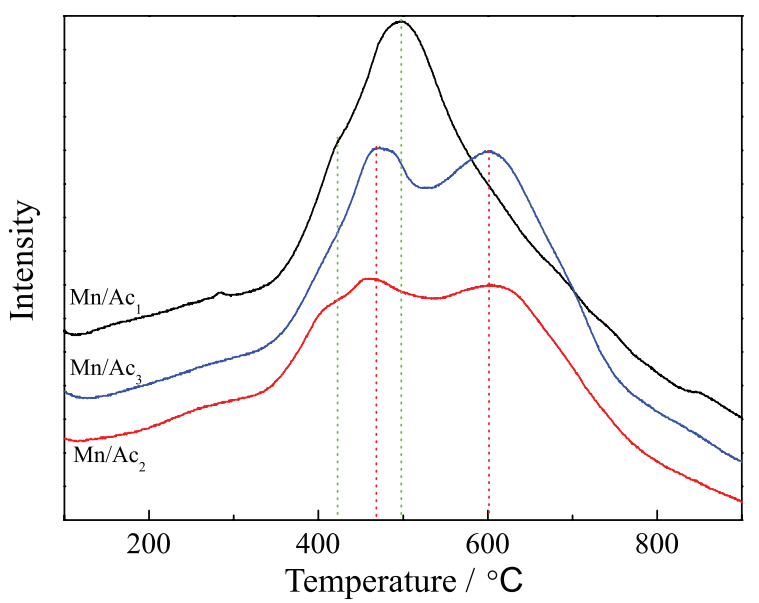

Figure 1. $\mathrm{H}_{2}$-TPR profiles of $\mathrm{Mn} / \mathrm{AC}_{\mathrm{x}}(\mathrm{x}=1,2,3)$ deoxidizers before reaction. 
$\mathrm{Mn} / \mathrm{AC}_{2}$ deoxidizers was higher than that of $\mathrm{Mn} / \mathrm{AC}_{1}$ and $\mathrm{Mn} / \mathrm{AC}_{3}$ deoxidizers at $200{ }^{\circ} \mathrm{C}$.

\section{X-ray diffraction analysis}

In order to investigate the effect of deoxidizer phase composition and crystal structure on deoxidation performance, the prepared $\mathrm{AC}_{\mathrm{x}}$ and $\mathrm{Mn} / \mathrm{AC}_{\mathrm{x}}$ deoxidizer were detected by the powder XRD patterns, as shown in Figure 2. For the $\mathrm{AC}_{\mathrm{x}}$ deoxidizer (Figures $2 \mathrm{a}$ and $2 \mathrm{~b}$ ), a broadband in the range of $20-30^{\circ}$ and a narrow peak at $2 \theta=26^{\circ}$ were detected due to the amorphous carbon structure, which corresponds to the (111) and (002) planes, respectively. In addition, it can be seen from the Figures 2a and $2 \mathrm{~b}$ that a significant $\mathrm{SiO}_{2}$ diffraction peak also appeared at $2 \theta=20.8,36.5,50.1$ and $68.1^{\circ}$, corresponding to (100), (110), (112) and (203) planes, respectively. It is suggested that $\mathrm{SiO}_{2}$ is an important component of the $\mathrm{AC}_{\mathrm{x}}$ deoxidizer. ${ }^{27}$ By comparing the XRD crystal structure of $\mathrm{AC}_{\mathrm{x}}$ before and after reaction, it can be found that the structure morphology of $\mathrm{AC}_{1}$ and $\mathrm{AC}_{2}$ deoxidizers hardly changed before and after reaction, while the carbon peak of $\mathrm{AC}_{3}$ at $26.5^{\circ} \mathrm{C}$ after deoxidation was significantly reduced. This indicates that the structural properties of $\mathrm{AC}_{1}$ and $\mathrm{AC}_{2}$ are relatively stable, and it is difficult to deoxidize at low temperatures, while $\mathrm{AC}_{3}$ deoxidizer has higher activity, and at a lower temperature, it can undergo a deoxidation reaction. This is consistent with the experimental results.

After $\mathrm{AC}_{\mathrm{x}}$ modification with potassium permanganate (Figure 2c), $\mathrm{SiO}_{2}, \mathrm{MnO}$ and $\mathrm{MnCO}_{3}$ diffraction peaks of $\mathrm{Mn} / \mathrm{AC}_{\mathrm{x}}$ deoxidizer were detected. $\mathrm{SiO}_{2}$ diffraction peak appeared at $2 \theta=30.6^{\circ}$, indexed to (110) reflection. The intensity of $\mathrm{SiO}_{2}$ diffraction peak decreased because $\mathrm{MnO}$ and $\mathrm{MnCO}_{3}$ on the $\mathrm{AC}_{\mathrm{x}}$ surface covered a part of $\mathrm{SiO}_{2} . \mathrm{MnO}$ diffraction peak appeared at $2 \theta=34.9,40.5,58.7,70.1$ and $73.8^{\circ}$, corresponding to (111), (200), (220), (311) and (222) planes, respectively. $\mathrm{MnCO}_{3}$ diffraction peak appeared at $2 \theta=31.5^{\circ}$, indexed to (104) reflection. The $\mathrm{MnO}$ phase is generally considered to have excellent low temperature activity. $\mathrm{MnO}$ diffraction peak intensity at $2 \theta=34.9$ and $40.5^{\circ}$ for $\mathrm{Mn} / \mathrm{AC}_{2}$ catalyst had a slight increase and the peak width was slightly narrow compared with $\mathrm{Mn} / \mathrm{AC}_{1}$
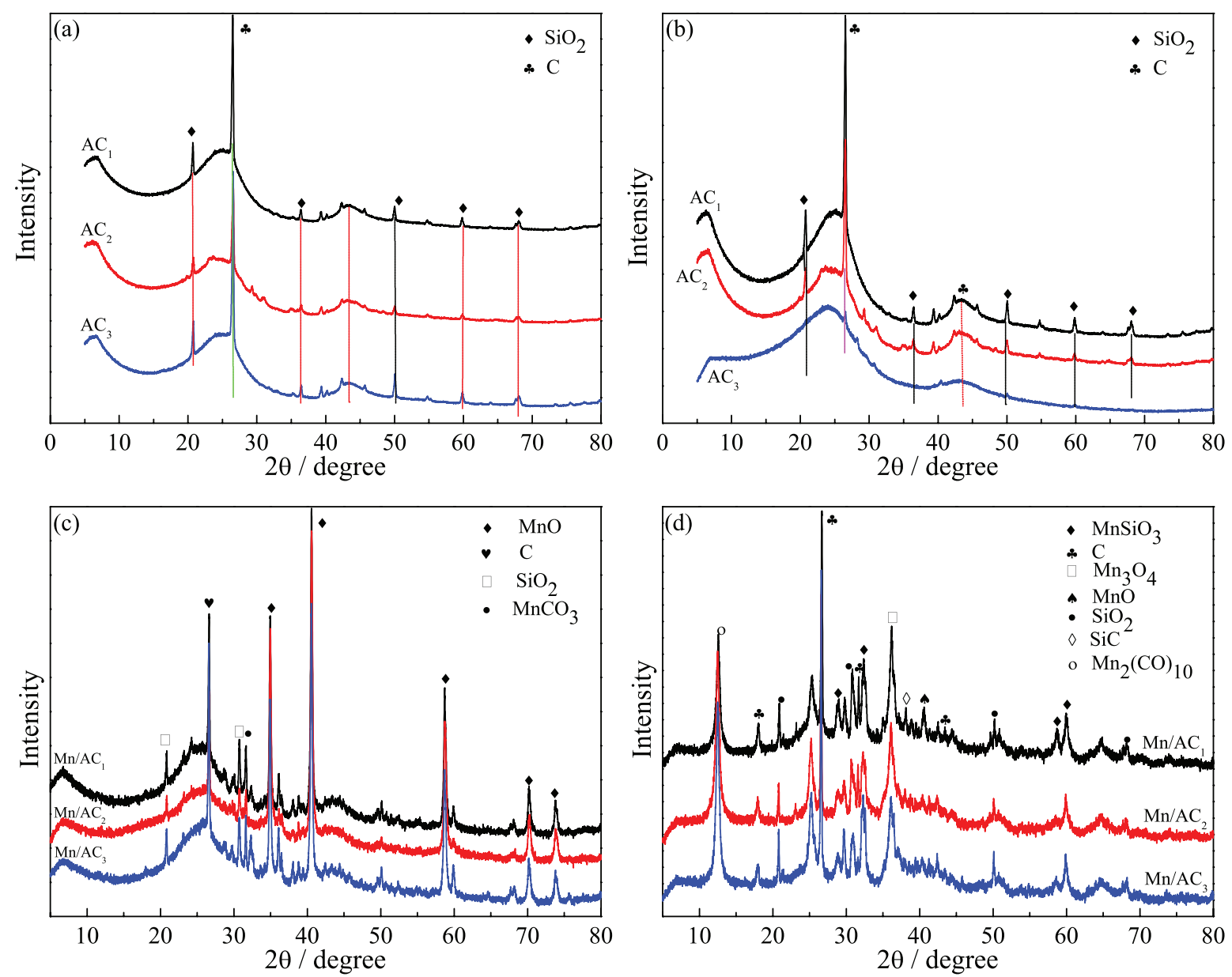

Figure 2. XRD patterns of before and after reaction of six deoxidizers: (a) $\mathrm{AC}_{\mathrm{x}}(\mathrm{x}=1,2,3)$ before reaction; (b) $\mathrm{AC}_{\mathrm{x}}(\mathrm{x}=1,2,3)$ after reaction; (c) $\mathrm{Mn} / \mathrm{AC}_{\mathrm{x}}(\mathrm{x}=1,2,3)$ before reaction; (d) $\mathrm{Mn} / \mathrm{AC}_{\mathrm{x}}(\mathrm{x}=1,2,3)$ after reaction. 
and $\mathrm{Mn} / \mathrm{AC}_{3}$ deoxidizers, indicating the distribution uniformity of manganese active component on the $\mathrm{AC}_{1}$ and $\mathrm{AC}_{1}$ surface became poor, so the deoxidation rate of $\mathrm{Mn} / \mathrm{AC}_{1}$ and $\mathrm{Mn} / \mathrm{AC}_{3}$ deoxidizer were lower than those of $\mathrm{Mn} / \mathrm{AC}_{2}$ deoxidizer. However, no peak of $\mathrm{MnO}_{2}$ was detected by $\mathrm{XRD}$, indicating that it exists in the amorphous phase or is highly dispersed on the $\mathrm{AC}_{\mathrm{x}}$ surface. The powder XRD patterns of calcined $\mathrm{Mn} / \mathrm{AC}_{\mathrm{x}}$ deoxidizer samples after reaction showed diffraction lines at $2 \theta=28.8,32.2,58.3$ and $59.7^{\circ}$ typical for cubic $\mathrm{MnSiO}_{3}$, and the diffraction signal at $2 \theta=36^{\circ}$ is ascribed to $\mathrm{Mn}_{3} \mathrm{O}_{4}$ (Figure 2d). The intensity of $\mathrm{MnO}$ diffraction peaks became weak, suggesting that the $\mathrm{MnO}$ phase structure transforms to the $\mathrm{Mn}_{3} \mathrm{O}_{4}$ and $\mathrm{MnSiO}_{3}$ phase. The activity of $\mathrm{MnO}$ was superior to that of $\mathrm{Mn}_{3} \mathrm{O}_{4}$ and $\mathrm{MnSiO}_{3}$ at the low temperature. The formation of $\mathrm{Mn}_{3} \mathrm{O}_{4}$ and $\mathrm{MnSiO}_{3}$ phase on the deoxidizer surface was to some extent responsible for the deoxidizer deactivation, so the deoxidation performance of $\mathrm{Mn} / \mathrm{AC}_{\mathrm{x}}$ decreased with the increase of the reaction time.

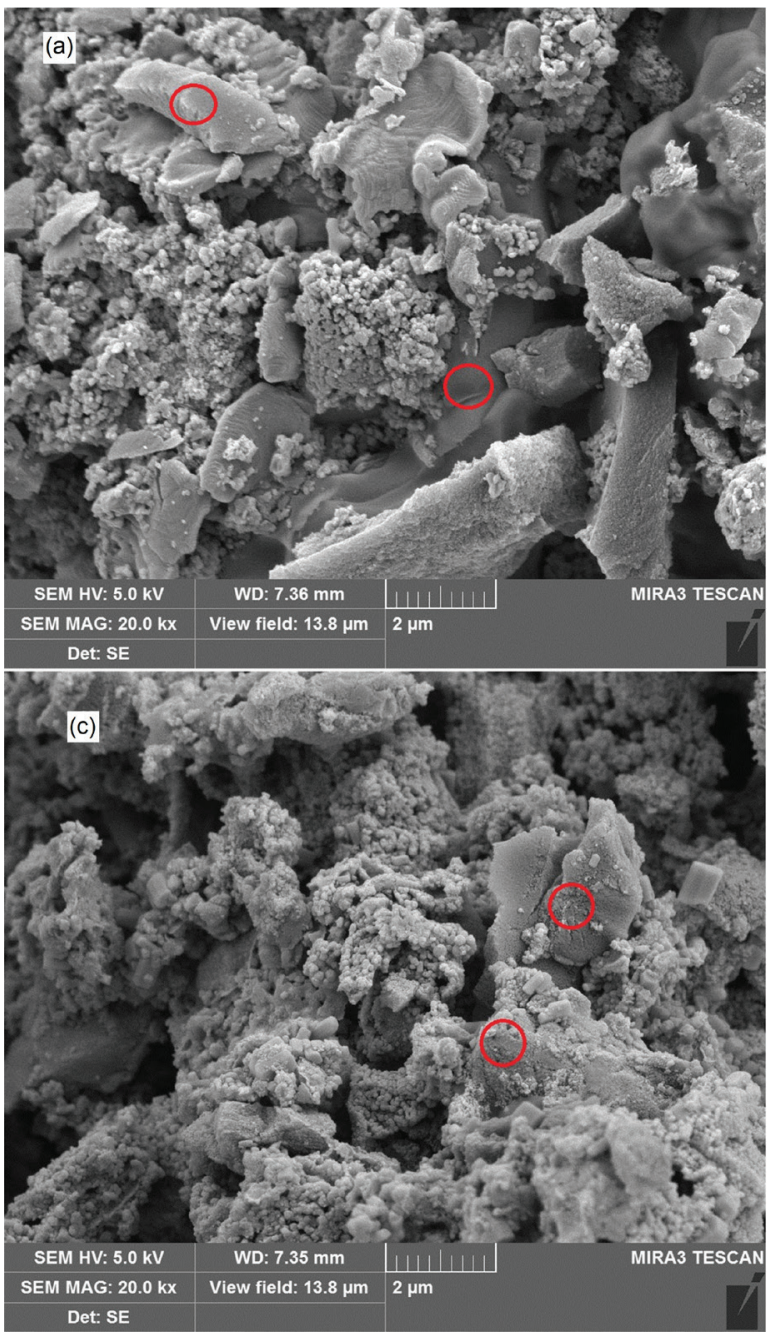

\section{SEM and EDS analysis}

Figure 3 shows the SEM images of the $\mathrm{Mn} / \mathrm{AC}_{1}$ and $\mathrm{Mn} / \mathrm{AC}_{2}$ deoxidizers before and after deoxidation reaction. It can be seen that the mapping of the two types of deoxidizers is completely different: the SEM images of $\mathrm{Mn} / \mathrm{AC}_{2}$ (Figure 3a) sample displayed the presence of $\mathrm{MnO}$ species (white spots) on the outer surface. Furthermore, for SEM images of $\mathrm{Mn} / \mathrm{AC}_{1}$, the $\mathrm{MnO}$ particles were agglomerated as clusters (Figure 3c), which appeared as white patches in SEM. Further, for $\mathrm{Mn} / \mathrm{AC}_{1}$ deoxidizer before and after deoxidation reaction, the surface morphologies have undergone significant changes as shown in Figure 3. After the deoxidation reaction, the surface of the sample became loose, mainly due to the participation of some carbon materials. Therefore, the surface of the sample is covered with a layer of gray matter, and at the same time, some pores in the deoxidizer are collapsed due to the reaction. ${ }^{20,28-30}$ It is consistent with the result of BET analysis.

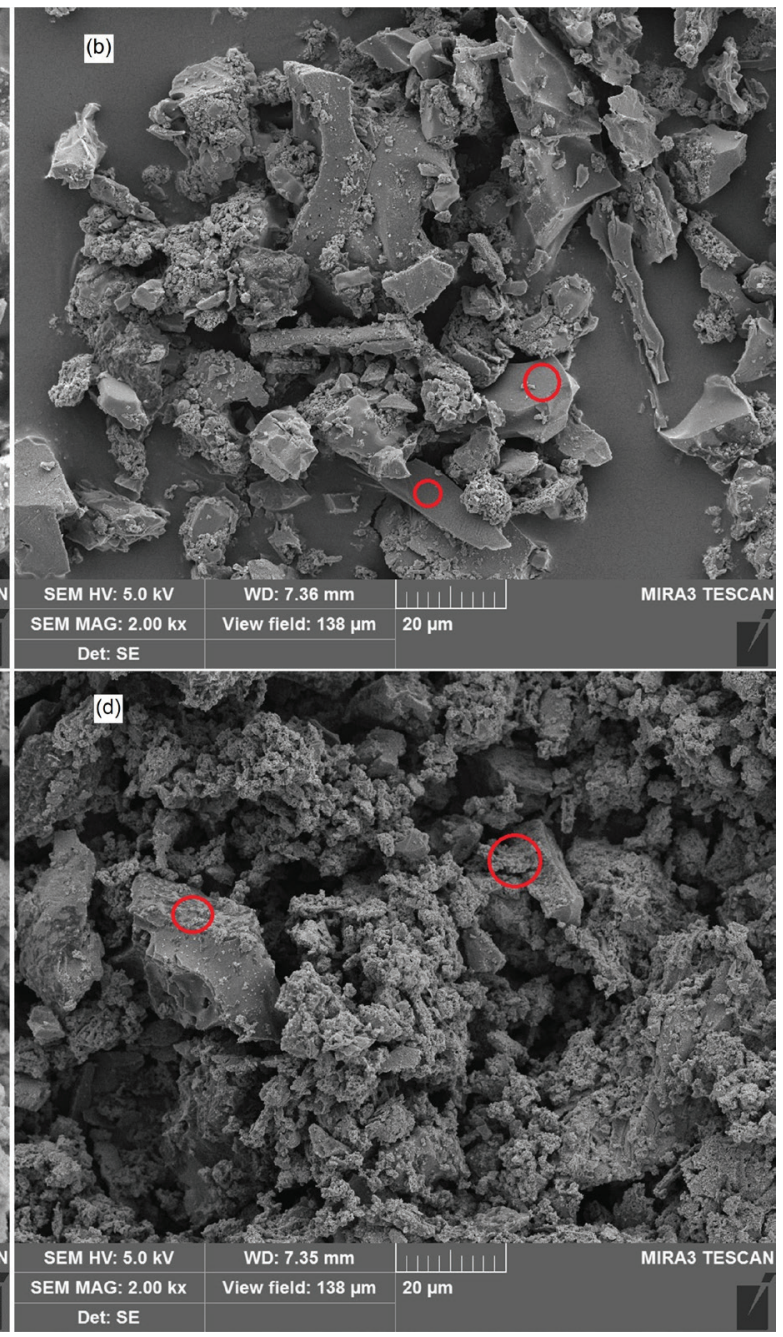

Figure 3. SEM images of deoxidizers before and after reaction. (a) $\mathrm{Mn} / \mathrm{AC}_{2}$ before reaction; (b) $\mathrm{Mn} / \mathrm{AC}_{2}$ after reaction; (c) $\mathrm{Mn} / \mathrm{AC} \mathrm{C}_{1}$ before reaction; (d) $\mathrm{Mn} / \mathrm{AC}_{1}$ after reaction. 


\section{TG analysis}

Figure 4 shows the $\mathrm{TG}$ and $\mathrm{DTG}$ (derivative thermogravimetry) curves for the $\mathrm{Mn} / \mathrm{AC}_{1}, \mathrm{Mn} / \mathrm{AC}_{2}$ and $\mathrm{Mn} / \mathrm{AC}_{3}$ deoxidizer. For $\mathrm{Mn} / \mathrm{AC}_{2}$, it can be seen that the weight loss of the deoxidizer in the temperature range of 40$800{ }^{\circ} \mathrm{C}$ can be divided into two segments. The weight loss below $200{ }^{\circ} \mathrm{C}$ is mainly due to the evaporation of free water and internal water in the deoxidizer. The weight loss step after the temperature is between 200 and $500{ }^{\circ} \mathrm{C}$ is mainly caused by the oxidation reaction of the deoxidizer with oxygen in the air. ${ }^{17}$ In addition, it can be seen from the DTG curve that after the temperature is higher than $200{ }^{\circ} \mathrm{C}$, the DTG rapidly decreases, and then tends to be stable after $500^{\circ} \mathrm{C}$. It shows that the deoxidation efficiency of the deoxidizer is higher at $200-500{ }^{\circ} \mathrm{C}$. The weight loss of the deoxidizer is about 59 wt. $\%$ between $200-500{ }^{\circ} \mathrm{C}$. Compared with $\mathrm{Mn} / \mathrm{AC}_{2}, \mathrm{Mn} / \mathrm{AC}_{3}$ have three weight loss stages: the first stage, which occurs at temperatures between 100 to $200{ }^{\circ} \mathrm{C}$, another stage at $300-500{ }^{\circ} \mathrm{C}$ with weight loss of ca. 35 wt.\%, and the third stage occurred at temperatures higher than $700{ }^{\circ} \mathrm{C}$. It demonstrated that the content of carbon, which is easy to be oxidized into $\mathrm{CO}_{2}$ on $\mathrm{Mn} / \mathrm{AC}_{3}$ is higher than $\mathrm{Mn} / \mathrm{AC}_{2}$. The shape of DTG curve of $\mathrm{Mn} / \mathrm{AC}_{1}$ is similar to $\mathrm{Mn} / \mathrm{AC}_{3}$, the second weight loss stage occurs at temperature between $200-600{ }^{\circ} \mathrm{C}$ with weight loss of ca. 60 wt. $\%$.

\section{FTIR analysis}

Figure 5 displays FTIR of six deoxidizers before and after reaction. As shown in Figures $5 \mathrm{a}$ and $5 \mathrm{~b}$, for $\mathrm{AC}_{\mathrm{x}}$ deoxidizer, absorption peaks at approximately 3420 , 1598, and $1087 \mathrm{~cm}^{-1}$ was observed. The absorption peak at $3420 \mathrm{~cm}^{-1}$ belongs to the stretching vibrations of hydroxyl, carboxyl, and surface adsorbed water. ${ }^{29,31-34}$ The absorption peak at $1560-1510 \mathrm{~cm}^{-1}$ with the main adsorption at $1598 \mathrm{~cm}^{-1}$ contributed to the $\mathrm{C}=\mathrm{O}$ stretching vibration of different functional groups, including ketone and carbonyl. ${ }^{31-33}$ The peak at $1300-900 \mathrm{~cm}^{-1}$ with the main adsorption at $1087 \mathrm{~cm}^{-1}$ belonged to the presence of the $\mathrm{C}-\mathrm{O}$ stretching of ester and $\mathrm{C}-\mathrm{OH} .{ }^{31,35-38}$ After the reaction (Figure $5 \mathrm{~b}$ ), it has been found that the absorption peak of $\mathrm{AC}_{1}$ and $\mathrm{AC}_{2}$ deoxidizer at $1087 \mathrm{~cm}^{-1}$ had no significant change. However, the $\mathrm{AC}_{3}$ absorption peak was significantly reduced at $1087 \mathrm{~cm}^{-1}$, while the peak at $1598 \mathrm{~cm}^{-1}$ was significantly enhanced and a new peak was produced at $1750 \mathrm{~cm}^{-1}$. The difference of the intensity and the slight shift of wavenumber of samples suggested a small difference in the surface chemistry of the samples. ${ }^{31,39}$ This indicates that $\mathrm{AC}_{3}$ deoxidizer has
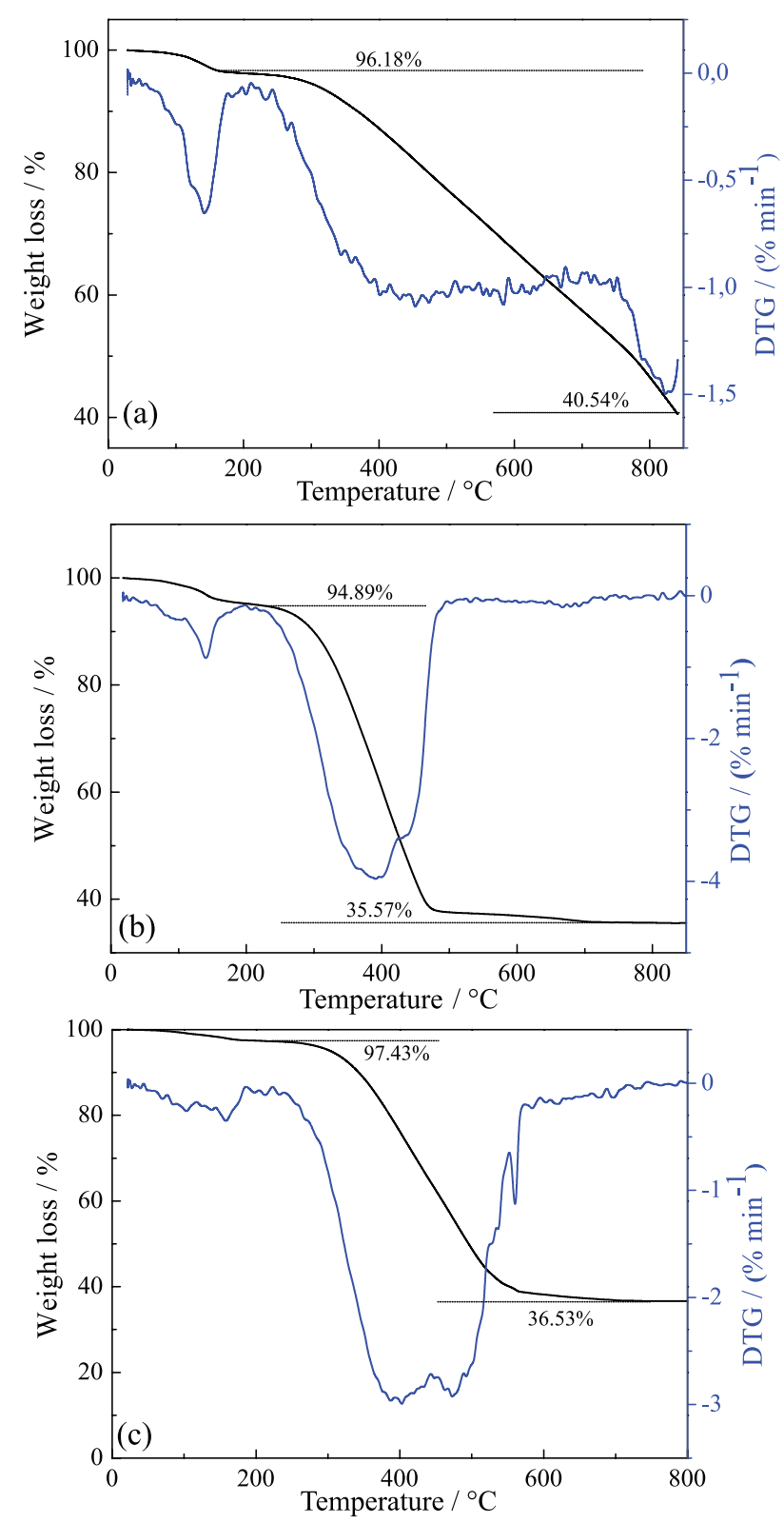

Figure 4. TG/DTG curves of (a) $\mathrm{Mn} / \mathrm{AC}_{2}$; (b) $\mathrm{Mn} / \mathrm{AC}_{3}$; (c) $\mathrm{Mn} / \mathrm{AC}_{1}$ under air.

good deoxidation activity. This is also consistent with the experimental results of deoxidation.

FTIR of $\mathrm{AC}_{\mathrm{x}}$ modification with potassium permanganate before and after reaction is shown in Figures $5 \mathrm{c}$ and $5 \mathrm{~d}$. As can be seen from the figure, for $\mathrm{Mn} / \mathrm{AC}_{\mathrm{x}}$ deoxidizer, absorption peaks at approximately 3420, 1655, 1450, 1087 and $601 \mathrm{~cm}^{-1}$ was detected. The absorption peak at $3420 \mathrm{~cm}^{-1}$ belonged to hydroxyl $\mathrm{OH}$ absorption peak; the one at approximately $1655 \mathrm{~cm}^{-1}$ belonged to the stretching $(\mathrm{C}=\mathrm{O})$ vibrations of carboxyl and carbonyl in acidic oxygen surface groups, which in turn play a vital role in metal adsorption. ${ }^{29,37}$ The peak at $1450 \mathrm{~cm}^{-1}$ belonged to $\mathrm{C}-\mathrm{H}$ stretching vibrations of methyl. ${ }^{38,40}$ The peak at $601 \mathrm{~cm}^{-1}$ 

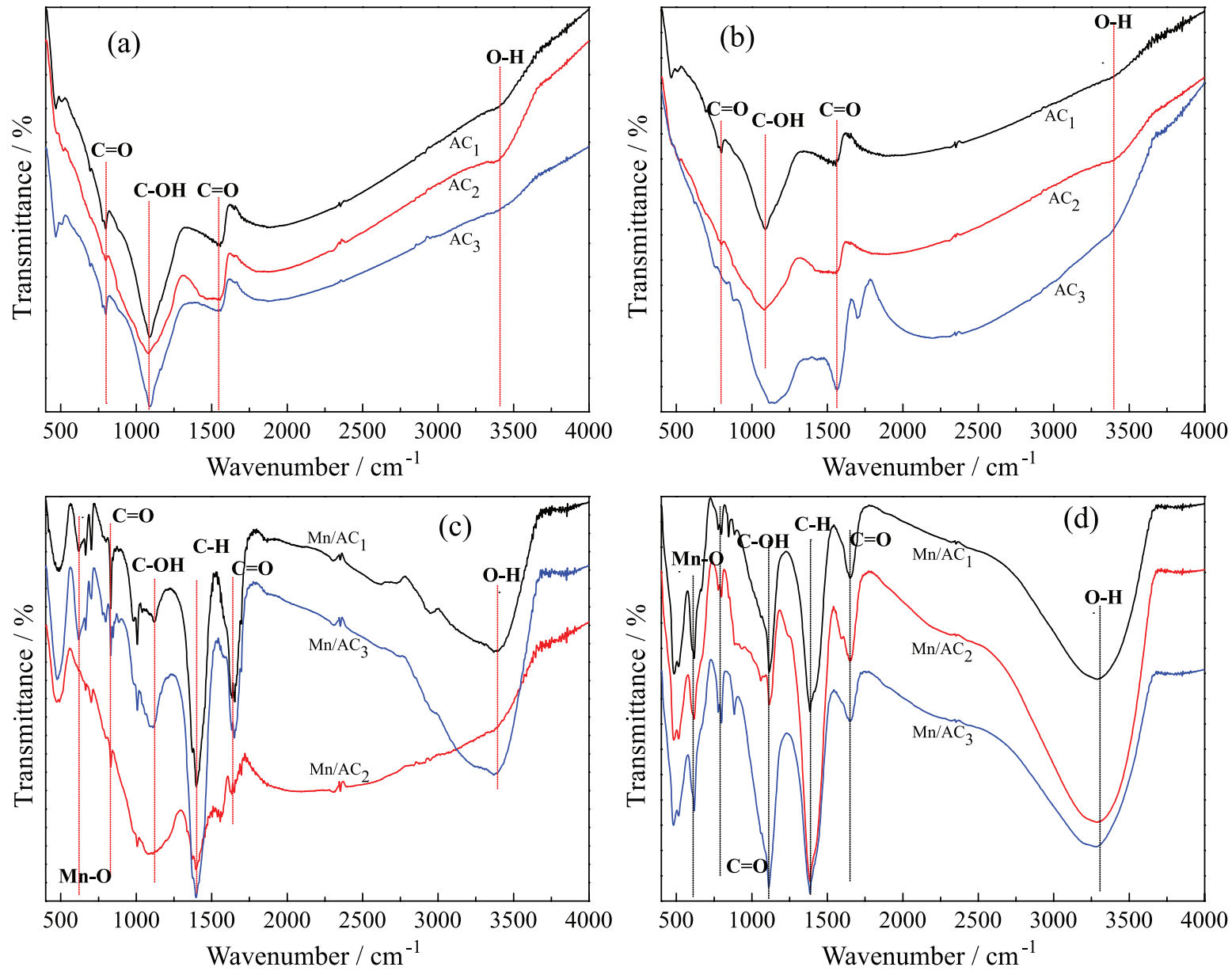

Figure 5. FTIR of six deoxidizers: (a) $\mathrm{AC}_{\mathrm{x}}(\mathrm{x}=1,2,3)$ before reaction; (b) $\mathrm{AC}_{\mathrm{x}}(\mathrm{x}=1,2,3)$ after reaction; (c) $\mathrm{Mn}_{\mathrm{AC}}(\mathrm{x}=1,2,3)$ before reaction; (d) $\mathrm{Mn} / \mathrm{AC}_{\mathrm{x}}(\mathrm{x}=1,2,3)$ after reaction.

belonged to the characteristic absorption of $\mathrm{Mn}-\mathrm{O} .{ }^{41}$ Compared with unmodified deoxidizer, it was found that two new peaks were produced at 1450 and $601 \mathrm{~cm}^{-1}$ for $\mathrm{Mn} / \mathrm{AC}_{\mathrm{x}}$ deoxidizer. Except for the two newly generated peaks, the peak positions of $\mathrm{AC}_{2}$ and $\mathrm{Mn} / \mathrm{AC}_{2}$ did not substantially change. The peak strengths of $\mathrm{Mn} / \mathrm{AC}_{1}$ and $\mathrm{Mn} / \mathrm{AC}_{3}$ at 3420,1655 and $1087 \mathrm{~cm}^{-1}$ were significantly stronger than those of $\mathrm{AC}_{1}$ and $\mathrm{AC}_{3}$. $\mathrm{C}-\mathrm{OH}$ absorption peak at $1087 \mathrm{~cm}^{-1}$ decreased, which is due to that under acid condition, the strong oxidizing potassium permanganate reacts with $\mathrm{C}-\mathrm{OH}$ in activated carbon. ${ }^{38,42}$ After reaction, the absorption peak at $1087 \mathrm{~cm}^{-1}$ was improved for all modified deoxidizer. Moreover, the absorption peaks at 3420,1655 and $1450 \mathrm{~cm}^{-1}$ were obviously improved for $\mathrm{Mn} / \mathrm{AC}_{2}$ deoxidizer. These changes indicate that electron transfer occurred between functional groups and $\mathrm{Mn}$ during the reaction. However, after the reaction, the other absorption peaks did not change significantly on $\mathrm{Mn} / \mathrm{AC}_{1}$ and $\mathrm{Mn} / \mathrm{AC}_{3}$, which indicates that the deoxidation activity of $\mathrm{Mn} / \mathrm{AC}_{1}$ and $\mathrm{Mn} / \mathrm{AC}_{3}$ is lower than that of $\mathrm{Mn} / \mathrm{AC}_{2}$.

\section{XPS analysis}

XPS studies were performed to determine the surface chemical state and elemental composition of $\mathrm{Mn} / \mathrm{AC}_{2}$ deoxidizer before and after reaction. The XPS survey spectrum of the representative sample $\mathrm{Mn} / \mathrm{AC}_{2}$ verifies the elements presence of $\mathrm{Mn}, \mathrm{C}$ and $\mathrm{O}$, as shown as follows.

\section{XPS analysis of manganese element}

The XPS patterns of the Mn $2 \mathrm{p}$ region for $\mathrm{Mn} / \mathrm{AC}_{2}$ deoxidizer are presented in Figures $6 \mathrm{a}$ and $6 \mathrm{~b}$. It can be found that the binding energy peak of $\mathrm{Mn} 2 \mathrm{p}_{3 / 2}$ and $\mathrm{Mn} 2 \mathrm{p}_{1 / 2}$ was located at about 642.1 and $653.8 \mathrm{eV}$, respectively, with an energy separation of $11.3 \mathrm{eV}$. The $\mathrm{Mn} 2 \mathrm{p}_{3 / 2}$ spectra were fitted with two characteristic peaks, which were assigned to $\mathrm{Mn}^{3+}$ and $\mathrm{Mn}^{4+}$ at 641.7 and $644.7 \mathrm{eV}$, respectively. $\mathrm{Mn}^{4+}$ and $\mathrm{Mn}^{3+}$ are considered to be the main valence states affecting the deoxidation properties of the deoxidizer. ${ }^{20,31,43-49}$ In order to accurately determine the oxidation state of manganese, $\mathrm{Mn} 3 \mathrm{~s}$ analysis was performed, as shown in Figures 6c and $6 \mathrm{~d}$. It can be found that the Mn 3 s core level peak of 
$\mathrm{Mn} / \mathrm{AC}_{2}$ deoxidizer shows peak splitting, and peak energy separation $(\Delta \mathrm{E})$ is observed at $5.15 \mathrm{eV}^{50,51}$ According to the linear relationship between $\Delta \mathrm{E}$ and the oxidation state of manganese, the average oxidation state of $\mathrm{Mn}$ is 3.5 for the $\mathrm{Mn} / \mathrm{AC}_{2}$ deoxidizer. After the deoxidation reaction, no valence change of Mn was observed from Figure $6 \mathrm{~b}$. However, it can be clearly seen from the analysis of $\mathrm{Mn}$ $3 \mathrm{~s}$ (Figure $6 \mathrm{~d}$ ) that the peak energy separation $(\Delta \mathrm{E})$ is significantly smaller, from the original 5.15 to 4.92 . Based on the linear relationship between $\Delta \mathrm{E}$ and the oxidation state of manganese, the $\mathrm{Mn}$ average oxidation state of the $\mathrm{Mn} / \mathrm{AC}_{2}$ deoxidizer increased from 3.5 to 3.6/3.7.

\section{XPS analysis of carbon element}

Figure 7 shows the $\mathrm{C} 1 \mathrm{~s}$ spectra of $\mathrm{Mn} / \mathrm{AC}_{2}$ deoxidizer before and after reaction. The $\mathrm{C} 1 \mathrm{~s}$ spectra could be divided into three peaks at 284.5, 285.0, and $286.8 \mathrm{eV}$, which indicates that there are different types of carbon species on deoxidizer surface. ${ }^{52}$ According to XPS standard values and related data, the binding energy at $284.5 \mathrm{eV}$ was assigned to graphite-like $\mathrm{C}-\mathrm{C}$ carbon, the binding energy at 285.0 assigned to alkyl $\mathrm{C}-\mathrm{C}$ carbon,
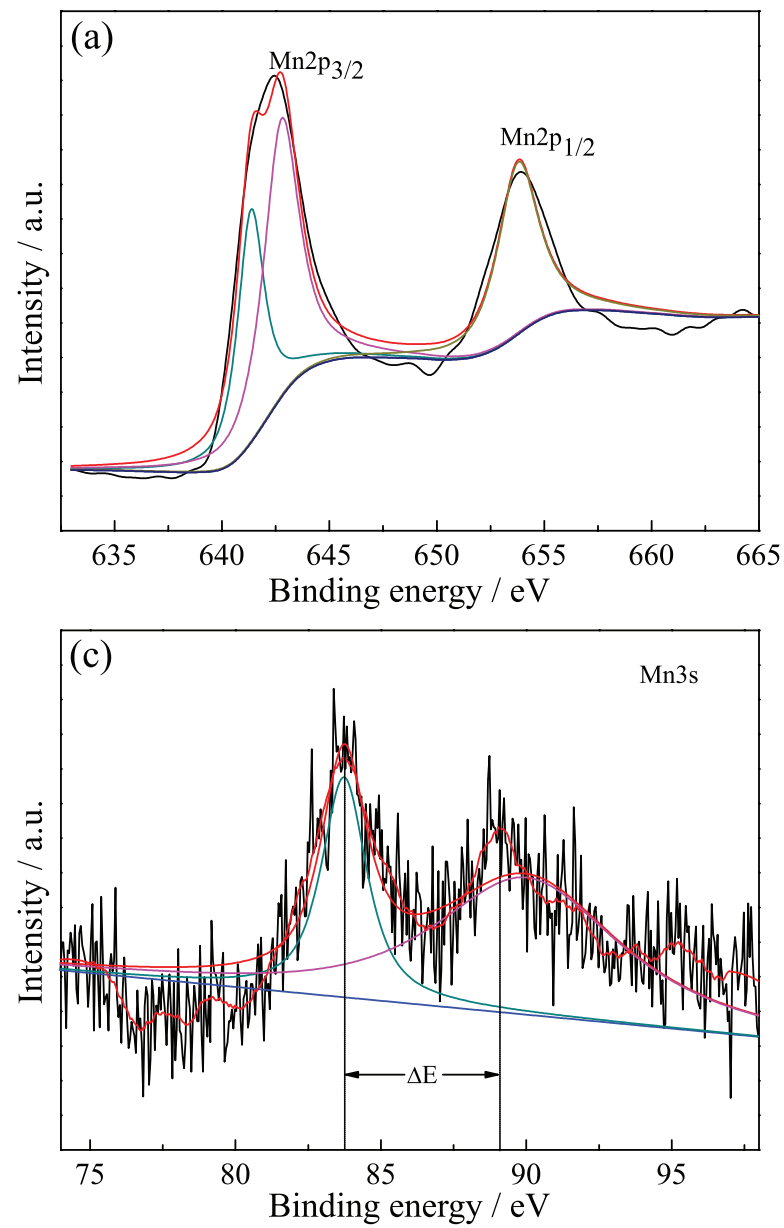

and the binding energy at 286.4-286.9 eV to carbonyl $\mathrm{C}=\mathrm{O}$ carbon. By comparing the results of Figures $7 \mathrm{a}$ and $7 \mathrm{~b}$, it can be found that the intensity of the graphite-like $\mathrm{C}-\mathrm{C}$ carbon structure increases, the alkyl $\mathrm{C}-\mathrm{C}$ carbon disappears, and the peak width of the carbonyl $\mathrm{C}=\mathrm{O}$ carbon decreases. This indicates that the alkyl $\mathrm{C}-\mathrm{C}$ carbon which is easily oxidized completely reacts with oxygen during the reaction. Due to the low reactivity of graphite carbon, the relative content in the sample is higher after the deoxidation reaction.

\section{XPS analysis of oxygen element}

Figure 8 shows XPS patterns of the $\mathrm{O} 1 \mathrm{~s}$ for $\mathrm{Mn} / \mathrm{AC}_{2}$ deoxidizer before and after reaction. For the $\mathrm{O} 1 \mathrm{~s}$ spectra of $\mathrm{Mn} / \mathrm{AC}_{2}$ deoxidizer, it can be found that two peaks were observed. It indicates that the different types of oxygen species are present on the surface of the deoxidizer. The peaks at $529-531 \mathrm{eV}$ is attributed to the binding energy of the lattice oxygen of the $\mathrm{Si}-\mathrm{O}$ bond in the $\mathrm{AC}$ framework and the $\mathrm{Mn}-\mathrm{O}-\mathrm{Mn}$ bond of the $\mathrm{Mn} / \mathrm{AC}_{2}$ deoxidizer. The binding energy of $531-534 \mathrm{eV}$ is attributed to chemisorbed oxygen. They can be assigned to defect oxides or the surface
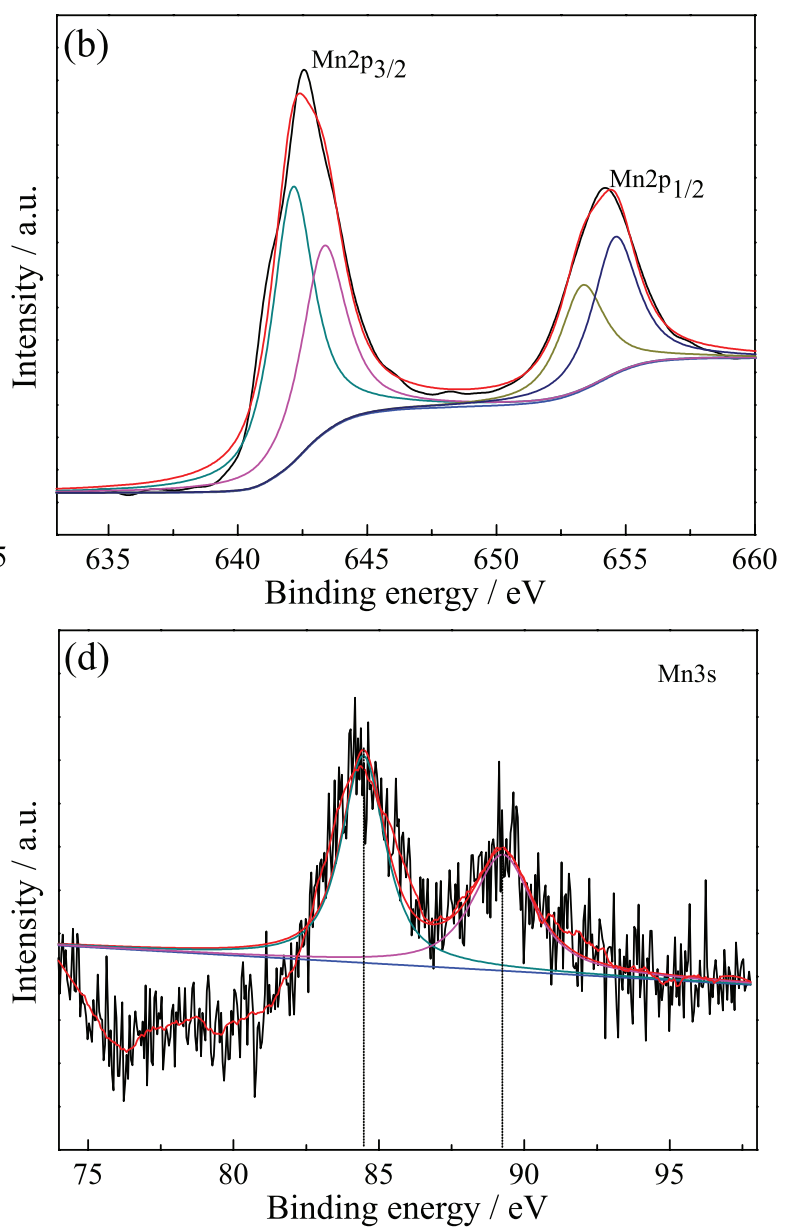

Figure 6. Mn spectra of $\mathrm{Mn} / \mathrm{AC}_{2}$ deoxidizer. (a) Mn 2p before reaction; (b) Mn 2p after reaction; (c) Mn 3s before reaction; (d) Mn 3s after reaction. 


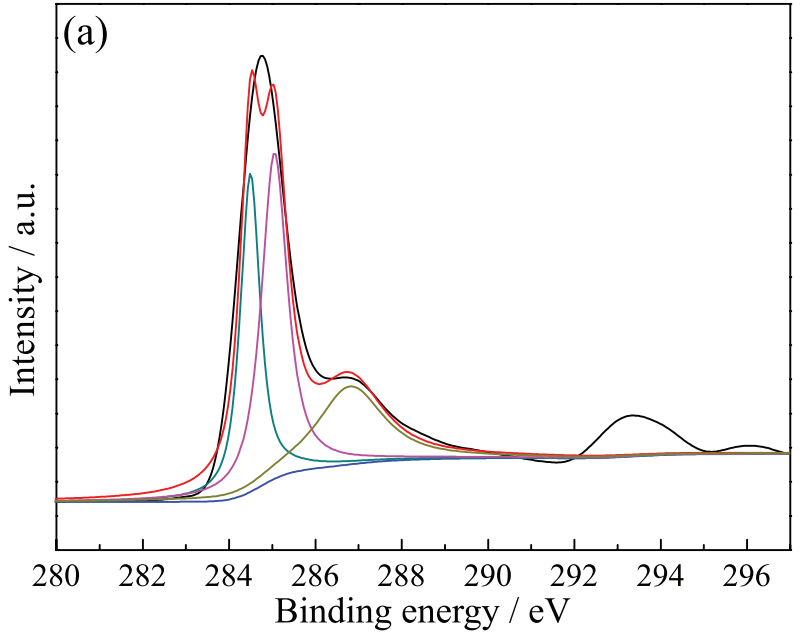

Figure 7. C 1s spectra of $\mathrm{Mn} / \mathrm{AC}_{2}$ deoxidizer (a) before and (b) after reaction.

oxygen ions with a low coordination. The abundance of chemisorbed oxygen, which has a higher mobility than the lattice oxygen in the $\mathrm{Mn} / \mathrm{AC}_{2}$ deoxidizer, was important for the low concentration coalbed methane deoxidation reaction. Comparing Figures $8 \mathrm{a}$ and $8 \mathrm{~b}$, the ratio of chemisorbed oxygen to lattice oxygen is significantly reduced after the reaction, this also demonstrates that the deoxidation activity of $\mathrm{Mn} / \mathrm{AC}_{2}$ deoxidizer decreased with reaction time.

\section{Deoxidation performance}

Higher deoxidation temperature is beneficial to oxidative deoxidation reaction, however, too high deoxidation temperature will cause decomposition or oxidation of methane, which is not conducive to methane enrichment. Therefore, temperature is a critical operating variable for deoxidation. ${ }^{17,53}$ Figure 9 shows the deoxidation activity of different deoxidizers at different deoxidation temperatures.

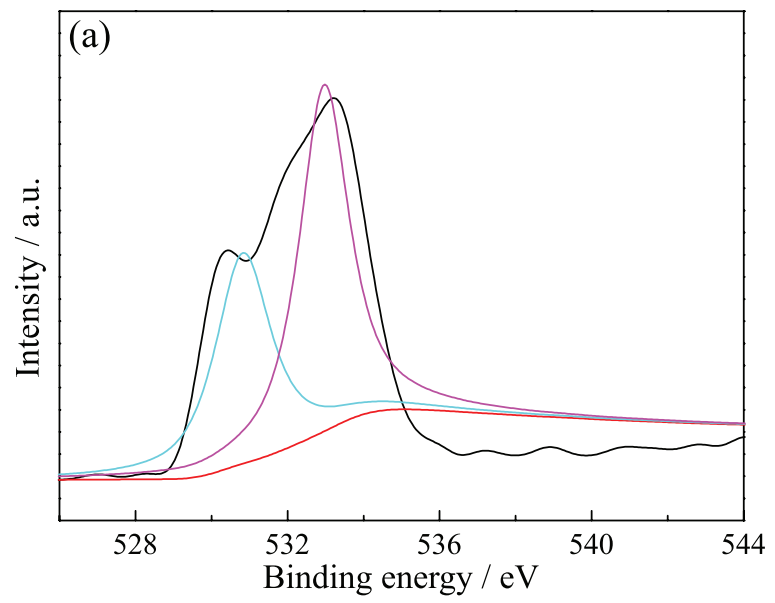

Figure 8. $\mathrm{O}$ 1s spectra of $\mathrm{Mn} / \mathrm{AC}_{2}$ deoxidizer (a) before and (b) after reaction.

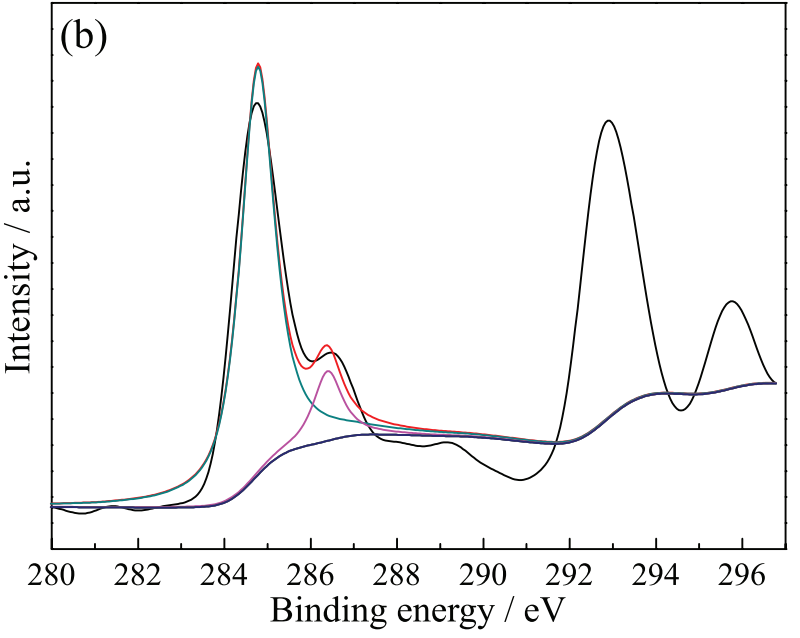

It can be seen that the original three activated carbons $\mathrm{AC}_{\mathrm{x}}(\mathrm{x}=1,2,3)$ exhibit the same deoxidation activity at different deoxidation temperatures. The order of activity is $\mathrm{AC}_{3}>\mathrm{AC}_{2}>\mathrm{AC}_{1}$. With the increase of deoxidation temperature, the deoxidation activity of activated carbon $\mathrm{AC}_{2}$ and $\mathrm{AC}_{1}$ remained unchanged. However, the deoxidation activity of activated carbon $\mathrm{AC}_{3}$ gradually increased. For $\mathrm{AC}_{3}$, the total deoxidation time (oxygen content $<0.5 \%$ ) can be maintained for about $100 \mathrm{~min}$ at a deoxidation temperature of $300{ }^{\circ} \mathrm{C}$, and the complete deoxidation time can be maintained for about $300 \mathrm{~min}$ when the deoxidation temperature is increased to $300{ }^{\circ} \mathrm{C}$. This difference is mainly due to that the activated carbon is made of different materials. Although activated carbons $\mathrm{AC}_{1}$ and $\mathrm{AC}_{2}$ are both coal-based activated carbon, the activity of $\mathrm{AC}_{2}$ is slightly higher than that of $\mathrm{AC}_{1}$, which could be attributed to the pore characteristic parameters (specific surface area, pore volume and pore diameter) of $\mathrm{AC}_{2}$ being superior to $\mathrm{AC}_{1}$. However, compared with the specific surface area of the three activated carbons, the specific surface area of $\mathrm{AC}_{3}$ is

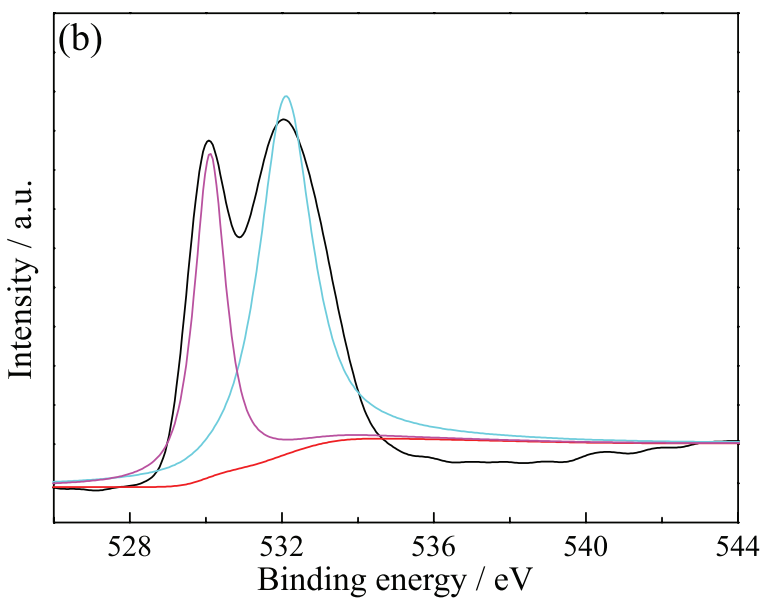



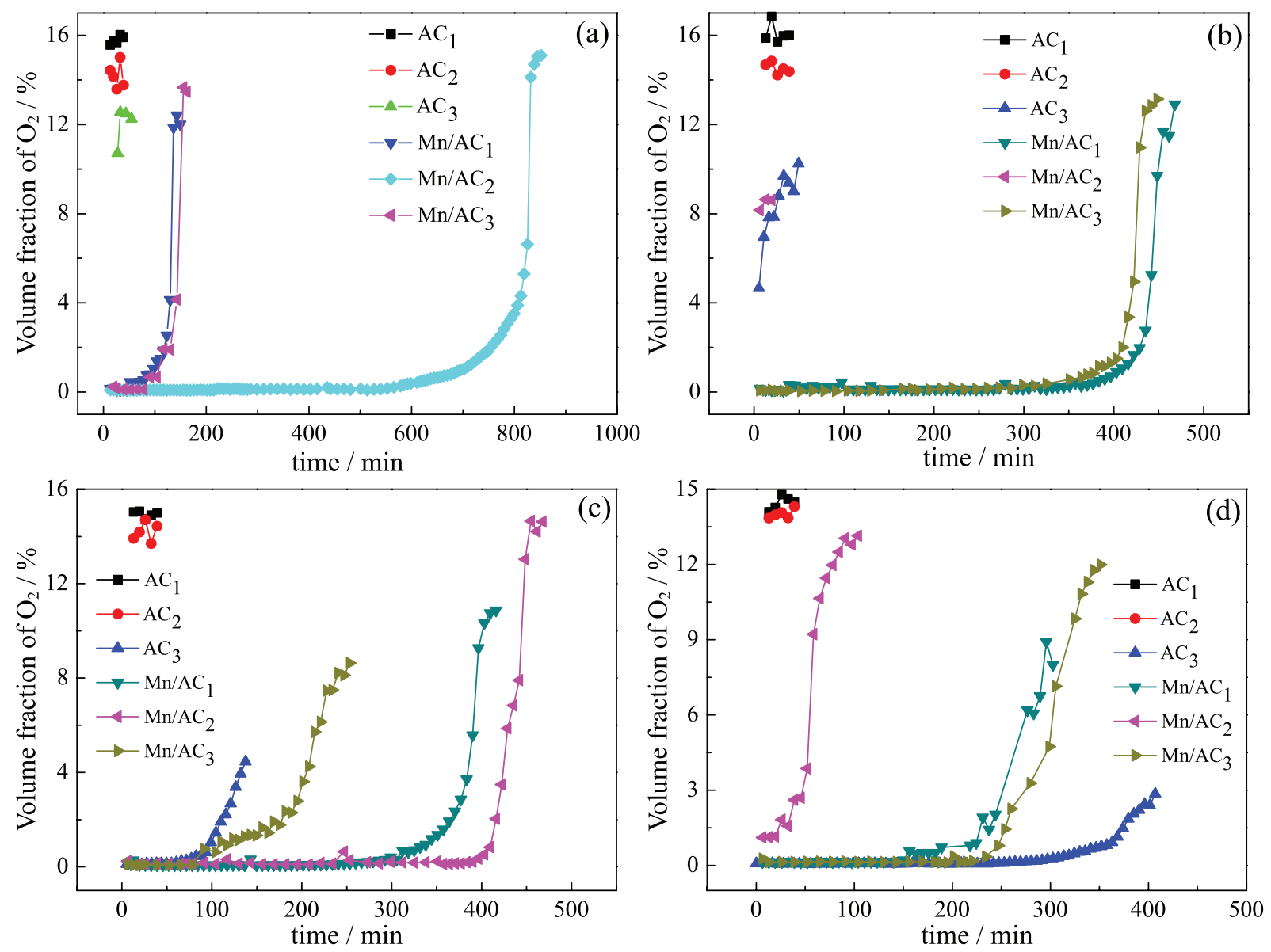

Figure 9. Reactive activity of the different deoxidizers at the different temperature showing oxygen concentration of outlet gas at (a) 200; (b) 250; (c) 300 and (d) $350{ }^{\circ} \mathrm{C}$.

significantly lower than that of $\mathrm{AC}_{1}$ and $\mathrm{AC}_{2}$, which indicates that the deoxidizing activity of different kinds of deoxidizers is not only related to the physical structure of oxidants, but also correlated with material itself being made.

The deoxidation activity of $\mathrm{Mn} / \mathrm{AC}_{\mathrm{x}}(\mathrm{x}=1,2,3)$ deoxidizer obtained was significantly improved compared with unmodified. Under the deoxidation condition of $200{ }^{\circ} \mathrm{C}, \mathrm{Mn} / \mathrm{AC}_{2}$ showed the best oxidation performance among all the potassium permanganate modified deoxidizer, and the time of complete deoxidation could reach about $600 \mathrm{~min}$. After further increasing the deoxidation temperature to $250{ }^{\circ} \mathrm{C}$, the deoxidation activity of $\mathrm{Mn} / \mathrm{AC}_{1}$ and $\mathrm{Mn} / \mathrm{AC}_{3}$ is also greatly improved, and the time for complete deoxidation of both can reach about $400 \mathrm{~min}$. The deoxidation rate of $\mathrm{Mn} / \mathrm{AC}_{2}$ is relatively low, about $50 \%$. This is mainly due to the fact that at the deoxidation at $200{ }^{\circ} \mathrm{C}$, more active functional groups and carbon materials are substantially consumed; while the relatively stable carbon species require higher activation energy to react with oxygen. As can be seen from Figure 9c, as the deoxidation temperature is further increased, the deoxidation activity of $\mathrm{Mn} / \mathrm{AC}_{\mathrm{x}}(\mathrm{x}=1,2,3)$ is further excited. However, when the deoxidation temperature increases to $350{ }^{\circ} \mathrm{C}$, the deoxidation rate of $\mathrm{Mn} / \mathrm{AC}_{2}$ rapidly decreases. This is mainly due to the fact that after deoxidation at $200-300{ }^{\circ} \mathrm{C}$ for nearly $1250 \mathrm{~min}$, the carbon material with higher activity in $\mathrm{Mn} / \mathrm{AC}_{2}$ is basically consumed. In addition, comparing Figures 9a-9d, it can be clearly found that the modified deoxidizer $\mathrm{Mn} / \mathrm{AC}_{\mathrm{x}}(\mathrm{x}=1,2,3)$ can significantly reduce the activation energy of the deoxidation reaction and improve the deoxidation characteristics of the sample. This is mainly because on the one hand potassium permanganate is a strong oxidizing substance and doping $\mathrm{Mn}$ as an additive in AC can react to its physicochemical properties and improves the reactive activity. On the other hand, after modification with potassium permanganate, the added Mn has a certain activity, which can promote the deoxidation reaction and reduce the activation energy of the deoxidation reaction. As can be seen from the comparison of Figures $9 \mathrm{~b}$ and $9 \mathrm{~d}$, for $\mathrm{AC}_{3}$ and $\mathrm{Mn} / \mathrm{AC}_{3}$ deoxidizers, the complete deoxidation starting temperatures were 250 and $350{ }^{\circ} \mathrm{C}$, respectively; and the total deoxidation retention time was approximately 300 and $350 \mathrm{~min}$, respectively. This indicates that the deoxidation temperature is reduced by at least 
$100{ }^{\circ} \mathrm{C}$ after modification with potassium permanganate. This provides a strong guarantee for deoxidation and enrichment of oxygen-containing coalbed methane, reducing methane loss and deoxidation temperature.

\section{Conclusions}

In a fixed-bed reactor, low-concentration coalbed methane deoxidation has been studied over different deoxidizers. The results show that the addition of potassium permanganate on $\mathrm{AC}_{\mathrm{x}}$ has greatly improved the deoxidation ability, compared with the original activated carbon $\mathrm{AC}_{\mathrm{x}}$. $\mathrm{Mn} / \mathrm{AC}_{2}$ catalyst exhibited the best deoxidation activity at 200-350 ${ }^{\circ} \mathrm{C}$ among all the $\mathrm{AC}_{\mathrm{x}}$ and $\mathrm{Mn} / \mathrm{AC}_{\mathrm{x}}$ deoxidizers. It indicates the modified deoxidizers lead to significant reduction of reaction barriers in the deoxidation reaction, which means that activated carbon is more favorable for oxygen adsorption and dissociation after potassium permanganate modification. In addition, due to the good adsorption performance of activated carbon, a large amount of manganese species is adsorbed on the surface of the activated carbon during the modification process. When activated carbon is used both as a carrier and as a reactant, these manganese species act as catalytically active components to promote the oxidation reaction. Under the combined action of the above several aspects, the activation energy of the oxidation reaction is lowered, and the deoxidation activity of $\mathrm{Mn} / \mathrm{AC}_{\mathrm{x}}$ is improved. Also, the functional groups on the surface of the activated carbons and valence state of metal and oxidized form have a certain type of influence on the activity of the deoxidating reaction.

\section{Supplementary Information}

Supplementary data (adsorption-desorption curves, pore size distribution and EDS mapping pattern) are available free of charge at http://jbcs.sbq.org.br as a PDF file.

\section{Acknowledgments}

This work was supported by the National Natural Science Foundation of China (Nos. U1610115, 21676174 and 21878200), International S\&T Cooperation Program of Shanxi Province (201703D421038), Shanxi Scholarship Council of China (2017-036), and Joint Fund of Shanxi Provincial Coal Seam Gas (2015012019).

\section{References}

1. Yang, Z.; Liu, J.; Zhang, L.; Zheng, S.; Guo, M.; Yan, Y.; RSC Adv. 2014, 4, 39394.
2. Cheng, Y. P.; Wang, L.; Zhang, X. L.; Int. J. Greenhouse Gas Control 2011, 5, 157.

3. Zhang, Q. F.; Wu, X. P.; Zhao, G. F.; Li, Y. K.; Wang, C. Z.; Liu, Y.; Gong, X. Q.; Lu, Y.; Chem. Commun. 2015, 51, 12613.

4. Karacan, C. Ö.; Ruiz, F. A.; Cotè, M.; Phipps, S.; Int. J. Coal Geol. 2011, 86, 121.

5. Li, Q. Y.; Wang, L.; Ju, Y. L.; CIESC J. 2011, 62, 1471.

6. Cui, G.; Li, Z. L.; Zhao, Y. L.; RSC Adv. 2015, 5, 68218.

7. Li, Y. L.; Liu, Y. S.; Yang, X.; Sep. Sci. Technol. 2013, 48, 1201.

8. Li, Y. L.; Liu, Y. S.; Int. J. Coal Prep. Util. 2013, 33, 72.

9. Li, Y. L.; Liu, Y. S.; Yang, X.; Adv. Mater. Res. 2011, 233-235, 2276.

10. Zhen, L.; Grande, C. A.; Ping, L.; Yu, J.; Rodrigues, A. E.; Sep. Purif. Technol. 2011, 81, 307.

11. Zhou, Y.; Fu, Q.; Shen, Y.; Sun, W.; Zhang, D.; Li, D.; Yan, H.; Energy Fuels 2016, 30, 1496.

12. Yang, X.; Liu, Y. S.; Li, Y. L.; Zhang, C. Z.; Meng, Y.; Yang, H. J.; J. China Coal Soc. 2011, 36, 91.

13. Lopes, F. V. S.; Grande, C. A.; Rodrigues, A. E.; Chem. Eng. Sci. 2011, 66, 303.

14. Gomes, G. V.; Hassan, M. M.; Sep. Purif. Technol. 2001, 24, 189.

15. Shimada, S.; Yoshitake, J.; J. Jpn. Inst. Energy 2013, 92, 536.

16. Zhao, P.; Zhang, G.; Sun, Y.; Xu, Y.; Environ. Sci. Pollut. Res. 2017, 24, 15240.

17. Hu, P.; Pan, H.; Lin, Q.; Cao, J.; Zhang, Y.; Zhao, M.; Energy Fuels 2018, 32, 6136.

18. Yang, L.; Huang, T.; Jiang, X.; Jiang, W.; Adsorption 2016, 22 , 1099.

19. Lee, Y. W.; Park, J. W.; Choung, J. H.; Choi, D. K.; Environ. Sci. Technol. 2002, 36, 1086.

20. Wu, J.; Zhao, Z.; Huang, T.; Sheng, P.; Zhang, J.; Tian, H.; Zhao, X.; Zhao, L.; He, P.; Ren, J.; Gao, K.; Catal. Commun. 2017, 93, 62 .

21. Li, W.; Tan, S.; Shi, Y.; Li, S.; Fuel 2015, 160, 35.

22. Biniak, S.; Szymański, G.; Siedlewski, J.; Światkowski, A.; Carbon 1997, 35, 1799.

23. Arena, F.; Torre, T.; Raimondo, C.; Parmaliana, A.; Phys. Chem. Chem. Phys. 2001, 3, 1911.

24. Gil, A.; Gandía, L. M.; Korili, S. A.; Appl. Catal., A 2004, 274, 229.

25. Mirzaei, A. A.; Shaterian, H. R.; Kaykhaii, M.; Appl. Surf. Sci. 2005, 239, 246.

26. Huang, Z. B.; Liu, B. S.; Wang, X. H.; Tang, X. Y.; Amin, R.; Ind. Eng. Chem. Res. 2015, 54, 11268.

27. Shukla, P. R.; Wang, S.; Sun, H.; Ang, H. M.; Tadé, M.; Appl. Catal., B 2010, 100, 529.

28. Chella, S.; Kollu, P.; Komarala, E. V. P.; Doshi, S.; Saranya, M.; Felix, S.; Ramachandran, R.; Saravanan, P.; Koneru, V. L.; Venugopal, V.; Jeong, S. K.; Gracea, A. N.; Appl. Surf. Sci. 2015, $327,27$. 
29. Zhang, J. J.; Wang, W. Y.; Shen, L. P.; Wang, G. J.; Song, H.; Adsorpt. Sci. Technol. 2016, 34, 331.

30. Pang, M.; Long, G.; Jiang, S.; Ji, Y.; Han, W.; Wang, B.; Liu, X.; Xi, Y.; Electrochim. Acta 2015, 161, 297.

31. Tian, Z.; Wang, C.; Si, Z.; Ma, L.; Chen, L.; Liu, Q.; Appl. Catal., A 2017, 541, 50.

32. Yang, H.; Yan, R.; Chen, H.; Lee, D. H.; Liang, D. T.; Zheng, C.; Energy Fuels 2006, 20, 1321.

33. Yang, H.; Yan, R.; Chen, H.; Lee, D. H.; Zheng, C.; Fuel 2007, 86, 1781.

34. Zhang, L.; Chang, X.; Li, Z.; He, Q.; J. Mol. Struct. 2010, 964 , 58.

35. Gomez-Serrano, V.; Pastor-Villegas, J.; Perez-Florindo, A.; Duran-Valle, C.; Valenzuela-Calahorro, C.; J. Anal. Appl. Pyrolysis 1996, 36, 71.

36. Sun, F.; Gao, J.; Zhu, Y.; Qin, Y.; Korean J. Chem. Eng. 2011, 28, 2218.

37. Li, Z.; Li, J.; Wang, Y.; Wei, Y.; Spectrochim. Acta, Part A 2014, $117,422$.

38. Yang, L.; Jiang, X.; Yang, Z. S.; Jiang, W. J.; Ind. Eng. Chem. Res. 2015, 54, 1689.

39. Fan, L.; Chen, J.; Guo, J.; Jiang, X.; Jiang, W.; J. Anal. Appl. Pyrolysis 2013, 104, 353.

40. Erabee, I. K.; Ahsan, A.; Jose, B.; Aziz, M. M. A.; Ng, A. W. M.; Idrus, S.; Daud, N. N. N.; KSCE J. Civ. Eng. 2018, 22, 1083.

41. Wang, M.; Zhang, P.; Li, J.; Jiang, C.; Chin. J. Catal. 2014, 35, 335 .
42. Zhang, G.; Sun, Y.; Zhao, P.; Xu, Y.; Su, A.; Qu, J.; J. CO2 Util. 2017, 20, 129.

43. Fan, L.; Jiang, X.; Jiang, W.; Guo, J.; Chen, J.; Adsorption 2014 , 20, 747.

44. Biesinger, M. C.; Lau, L. W.; Gerson, A. R.; Smart, R. S. C.; Appl. Surf. Sci. 2010, 257, 887.

45. Chen, J.; Zhu, B.; Sun, Y.; Yin, S.; Zhu, Z.; Li, J.; J. Braz. Chem. Soc. 2018, 29, 79.

46. Dai, F.; Yu, Y.; Meng, M.; Zhang, J.; Zheng, L.; Hu, T.; Catal. Lett. 2014, 144, 1210.

47. Jang, D. I.; Park, S. J.; Fuel 2012, 102, 439.

48. Deng, J.; He, S.; Xie, S.; Yang, H.; Liu, Y.; Guo, G.; Dai, H.; Environ. Sci. Technol. 2015, 49, 11089.

49. Gallegos, M. V.; Peluso, M. A.; Finocchio, E.; Thomas, H. J.; Busca, G.; Sambeth, J. E.; Chem. Eng. J. 2017, 313, 1099.

50. Galakhov, V. R.; Demeter, M.; Bartkowski, S.; Neumann, M.; Ovechkina, N. A.; Kurmaev, E. Z.; Lobachevskaya, N. I.; Mukovskii, Y. M.; Mitchell, J.; Ederer, D. L.; Phys. Rev. B: Condens. Matter Mater. Phys. 2002, 65, 113102.

51. Li, L.; Diao, Y.; Xiu, X.; J. Rare Earth 2014, 32, 409.

52. Seok, S. H.; Han, S. H.; Lee, J. S.; Appl. Catal., A 2001, 215, 31.

53. Ren, J.; Xie, C.; Lin, J.; Li, Z.; Process Saf. Environ. Prot. 2014, $92,896$.

Submitted: November 14, 2018

Published online: May 8, 2019 